\title{
Factors that determine the evolution of high-growth businesses
}

\author{
Oriol Amat, ${ }^{1}$ Marcos Antón Renart, ${ }^{2}$ María José García ${ }^{3}$ \\ ${ }^{1}$ Universitat Pompeu Fabra, ${ }^{2}$ Universidad de Murcia, ${ }^{3}$ Universidad Rey Juan Carlos (Spain) \\ oriol.amat@upf.edu, mantonr@um.es,_mariajose.garcia@urjc.es
}

Received: June 2013

Accepted: July 2013

\section{Abstract}

Purpose: The study herein discusses research aimed at elucidating the factors that contribute to a business' ability to maintain high growth.

Design/methodology/approach: The database from the Iberian Balance Sheet Analysis System (SABI, from its initials in Spanish) was used to identify 250 industrial Catalonian businesses with high growth during 2004-2007. These companies participated in a survey on strategies and management practices; in 2013, they were re-analyzed to investigate the factors that contributed to continued growth for certain companies.

Findings: Through diverse statistical techniques, business policies related to quality, innovation, internationalization and finance were shown to influence business growth and sustainability over time.

Research limitations: This study focuses on industrial businesses at least ten years old in Catalonia; thus, the conclusions may differ in other geographic locations and economic sectors, as well as for smaller businesses.

Practical implications: Because growth is a measure of business success, identifying variables that contribute to high growth and its sustainability is helpful for businesses that seek to adopt effective policies.

Social implications: Generating employment is one of the primary contributions by high-growth businesses. For years with high unemployment, authorities may be interested in corporate policies that strengthen high-growth businesses. 
Originality/value: High-growth businesses have been studied throughout the world, but this is the first study to investigate the evolution of businesses after a high-growth phase.

Keywords: quality, high-growth businesses, business evolution, financial information, innovation, internationalization

JEL Codes: M1-Business Administration

\section{Introduction}

Businesses succeed through achieving objectives (Fisher \& Reuber, 2003); growth is a priority for many businesses (Goedhuys \& Sleuwaegen, 2010).

This study examines high-growth businesses. According to the literature, the key variable for high growth is typically sales growth. The most common definition of a high-growth business is that it has at least a $20 \%$ annual sales growth rate for three years (Eurostat, 2007). Because certain studies also restrict the number of employees, a 10-employee minimum was required herein. Therefore, this study defines high-growth businesses as businesses with a $20 \%$ sales growth minimum for three consecutive years with at least 10 employees.

Business growth and its determining factors are relevant for multiple reasons; for example, high-growth businesses promote a country's economic growth because more high-growth businesses enhance GDP growth (Hoffmann \& Junge, 2006). Such businesses also generate more employment than their competitors (Henrekson \& Johansson, 2008), which is especially interesting during high unemployment. For example, Birch and Medoff (1994) estimate that high-growth businesses, which compose $4 \%$ of total businesses accounted for $60 \%$ of new jobs in the United States between 1988 and 1992. Notably, such businesses return high yields to investors (Acs, Parsons \& Tracy, 2008).

Given that businesses are interested in high growth, it is especially important to identify the factors that promote such growth (Serarols \& Urbano, 2007). Furthermore, it is relevant to identify the factors that contribute to maintaining such high growth over time. An analysis for competitiveness typically includes three levels (ESADE, 1996): the general economic framework of the country or territory used for operations, sectoral context and business strategy.

This study analyzes the evolution of high-growth businesses and evaluates whether such businesses can maintain their sales, earnings and employee growth over time. Thus, the 
objective of this article was to identify factors that contribute to maintaining high growth in businesses.

\section{Literature review}

\section{Business growth}

Business growth can be explained from different theoretical perspectives (Coad, 2009): neoclassical theory, dynamic analysis, entrepreneurial initiative theories, evolutionary economics and organizational ecology.

In the neoclassical theory, the primary business objective is to reach the "optimum dimension," which is the productivity level with the greatest profit. From this perspective, growth is not the primary goal, but it is a means to reach the "optimum dimension" (Coad, 2009).

Penrose's (1959) dynamic analysis attributes a business' competitive advantage to endogenous factors resources and abilities.

From the entrepreneurial initiative perspective, business scale and growth are relevant to executive or entrepreneurial utility functions (Marris, 1963). This theory predicts that such agents (in this case, the executives) who maximize utility also maximize business growth, as long as the compensation is sufficiently motivating.

Evolutionary economics departs from the neoclassical ideas equilibrium as well as static optimization and offers a more dynamic vision. Alchian (1950) provides evolutionary mechanism theories that support economic expansion during which more solid businesses survive, but the less viable businesses lose market share and fail. Downie (1958) defends the hypothesis that profit reinvestment is decisive to business growth. Nelson and Winter (1982) propose a theoretical model that explains competition between businesses in a changing context. Under this model, businesses have a competitive advantage through discovering innovations that reduce production cost or imitate the market's best production practices. The most productive and profitable businesses grow, while the less successful fail.

Finally, beginning with the Hannan and Freeman study (1977), organizational ecology theories use economic, sociological and biological elements to analyze the conditions that determine business creation, evolution and failure. Primary predictions by various branches of organizational ecology theory include such predictions that explain business growth through discovering niches with valuable and unique resources. The earnings that such niche businesses can generate (which facilitate rapid growth) attract new organizations. The number of competitors is limited by inadequate resources and expansion paths. 


\section{Factors that favor business growth}

The impetus for growth is also relevant and includes size, age, innovation and funding source availability.

The majority of studies agree that smaller businesses tend to grow faster (Lotti, Santarelli \& Vivarelli, 2003).

Various studies (Evans, 1987; Yasuda, 2005) have shown a negative relationship between growth and age.

Evidence suggests that R\&D investment increases competitiveness and sales (Freel, 2000; Moraleda, 2004).

Funding availability is an important incentive for profitable growth. Multiple studies have examined the relationship between growth and access to funds. The most common thesis is that inadequate financial resources impede business growth, especially for small or new businesses (Cabral \& Mata, 2003). The effect is less pronounced for larger businesses (Bechetti \& Trovato, 2002). Therefore, small businesses with difficulty accessing funds grow more slowly than others.

Based on the above discussion, this study assumes that rapid business growth implies a strategic shift. Such a shift affects the company organization and necessitates that multiple opportunities that require specific entrepreneurial skills are recognized and used (Moreno \& Casillas, 2007).

\section{Previous studies on high-growth businesses in Spain and Catalonia}

Many studies have been conducted on high-growth businesses in Spain, most notably with the Galician (Cabanelas \& Vaamonde, 1995), Basque (Cabanelas \& Vaamonde, 1996), Aragonese (Galve \& Hernández, 2007) and Andalucian (Villalba, Muñoz, Román, Morilla, Pérez, Díaz et al., 2008) companies. These studies demonstrate the importance of a business strategy.

Various studies on high-growth businesses have been conducted in Catalonia. Hernández, Amat, Fontrodona and Fontana (1999) shows that high-growth businesses during 1994-1997 created value based on investments in human resources, innovation, process excellence, client satisfaction and prudent finances; the majority of earnings were reinvested. Amat, Fontrodona, Hernández and Stoyanova (2010) analyzed high-growth businesses during 2004-2007 with similar results to Hernández et al. (1999). By analyzing how the same businesses evolved after their high-growth phase, it is clear that few companies maintain high growth for more than 
four consecutive years. These data are surprising because most of the years after such businesses' high-growth phases were boom years for the country's economy.

These data demonstrate the relevance of research that elucidates the contributing factors to maintaining high-growth in business.

\section{Empirical research design}

Consistent with the research objective, the study herein included the following items.

Utilizing the high-growth business sample during 2004-2007: The sample was selected by Amat et al. (2010). The businesses were industrial; thus, their primary activity is industrial according to the National Classification of Business Activities, which is used by businesses for their annual accounting summary with the Commercial Registry.

The Iberian Balance Sheet Analysis System (SABI, for its initials in Spanish), which gathers and reports data from the Commercial Registry, was used to identify high-growth businesses. Businesses were selected from 141,071 Spanish companies with at least 10 employees that presented accounting summaries in 2007; 29,278 were Catalonian businesses. The indicator used to differentiate high-growth businesses was invoicing (net turnover). Following the Eurostat (2007) definition, the criterion at least a $20 \%$ annual sales increase was adopted.

For this study, high-growth businesses are defined as industrial businesses based in Catalonia that presented an annual accounting report to the Commercial Registry with at least 10 employees during 2004 and at least a 20\% invoicing increase during 2005-2007.

Using the established criteria, 250 high-growth businesses were identified in Catalonia. These companies represent $0.23 \%$ of the industrial businesses in Catalonia according to SABI data.

Strategies and management practices survey: The 250 high-growth businesses were used for a 2008 survey on strategies and management practices.

The questionnaire attempted to determine the importance of six key factors in business productivity: human resources and training; innovation and quality; internationalization; marketing; financing; activity subsector; and family ownership.

The response rate was $50.4 \% ; 126$ of the 250 businesses returned a fully or partially completed questionnaire. This study analyzed the responses from 2008, when the companies were identified as high-growth. Thus, the correlations between the business strategies in 2008 and business evolution in the following years were analyzed. 
Analysis of the economic-financial situation several years after entering the high-growth phase: In January 2013, the 126 high-growth businesses from the 2009 survey were analyzed. Thus, this survey was used to explore the factors that determine whether a business maintains growth. An accounting analysis identified the business that maintained growth, grew somewhat or contracted using the sales, profits and number of employees.

Analysis of the factors that determine sustainable growth: Finally, various statistical analyses were conducted to identify the determining factors that underlie the evolution disparities for the sampled businesses after entering the high-growth period. The statistical analysis process was as follows.

In the first phase, the data were refined. To conduct the regressions, the binary data were homogenized ( $1=$ yes and $0=$ no), and indicators were introduced to quantitatively measure the questions, such as the question on training level.

Because the behavior of the three growth variables (sales, profits and number of employees) was examined and was identical for the businesses analyzed, they were grouped into a single variable as an indicator of «growth». This indicator was used as a dependent variable.

Once refined, a regression analysis was applied to the grouped variables.

- Human resources and training (training expenditures, training plan, work survey administration, personal development plan and workforce training level).

- Innovation and quality (sales returns, environmental policy, quality certification, percent of R\&D expenditure to sales, an R\&D department and the new product sales percentage).

- Internationalization (internationalization through collective action, intermediaries, representatives and/or a matrix as well as export percentage).

- Marketing (new forms of pricing, new product placements, new promotion techniques, new product designs investment percentage for the business' own brands).

- Financing (percentage of a business' own resources used for financing) and other strategies such as product diversification, divestment in non-lucrative products and new management practices).

- Cooperation with other businesses, the activity subsector and family ownership (collaborative agreements with other companies, acquiring other businesses, family control of the business and the activity subsector). 
Tables were used to describe the percentage of "Yes, a lot," "Yes," or "No" answers for sales, profits and employee growth in each variable. Such analyses better detail how the results were produced for each variable that influences growth, and they corroborate the critical values in Student's t-distribution table.

Finally, in a complementary study, the values were compared using contingency tables and by calculating Pearson's chi-squared test values for each variable.

\section{Results}

\section{Evolution after entering a high-growth phase}

To analyze evolution for businesses that entered the high-growth phase during 2004-2007, their 2011 accounting records were analyzed using the SABI database. Because accounting records do not appear in the database until over a year after they close out, the 2013 study used the annual accounting records through 2011. As surveys were only received from 126 of the 250 high-growth businesses, the following analysis is based such survey results.

\section{Maintaining high-growth businesses}

Considering the economic crisis that began in 2008, more high-growth businesses survived compared with other businesses. For the 126 companies with high growth during 2004-2007, evolution thereafter was disparate (see table 1). The percentage of businesses with sustained high growth through 2011 was $8.74 \%$, while $19.85 \%$ had a sales growth similar to the inflation rate. The majority $(63.49 \%)$ had reduced sales, which is logical considering that these years included a significant drop in the country's economic activity. The remaining businesses were taken over, are in bankruptcy or do not exist.

\begin{tabular}{|l|r|r|}
\hline \multicolumn{1}{|c|}{ Business status at the end of $\mathbf{2 0 1 1}$} & Number of Businesses & \multicolumn{1}{c|}{$\%$} \\
\hline Continue activities and maintain high growth & 11 & $8.74 \%$ \\
\hline Continue activities but with slow growth (similar to inflation) & 25 & $19.85 \%$ \\
\hline Continue activities with reduced sales & 80 & $63.49 \%$ \\
\hline Were taken over & 2 & $1.58 \%$ \\
\hline Bankruptcy & 6 & $4.76 \%$ \\
\hline Do not exist & 2 & $1.58 \%$ \\
\hline Total & $\mathbf{1 2 6}$ & $\mathbf{1 0 0 . 0 0 \%}$ \\
\hline
\end{tabular}

Table 1. 2011 status for businesses with high growth during 2004-2007 


\section{Determining Factors for Growth Evolution}

The adjusted R-squared value indicates variation in the dependent variable "growth," which is explained by the independent variables in each model. When the value is higher, the variable group had more influence.

- Human resources and training: 0.073

- Innovation and quality: 0.414

- Internationalization: 0.238

- Commercialization: 0.039

- Financing: 0.219

- Cooperation with other businesses, activity subsector and family ownership: 0.017

Such values indicate that the most influential policies on growth for the businesses studied are innovation and quality; internationalization; and financing.

Figure 1 includes a summary of each variable's Student's t-test results. For the 126 businesses, considering that sales, profits and workers are typically distributed in each variable, this is a recommended statistic. Values greater than 2 (1.9799) for Student's t-test in our sample indicate an error less than 0.05 for the variable's influence (positive and negative) on "growth."

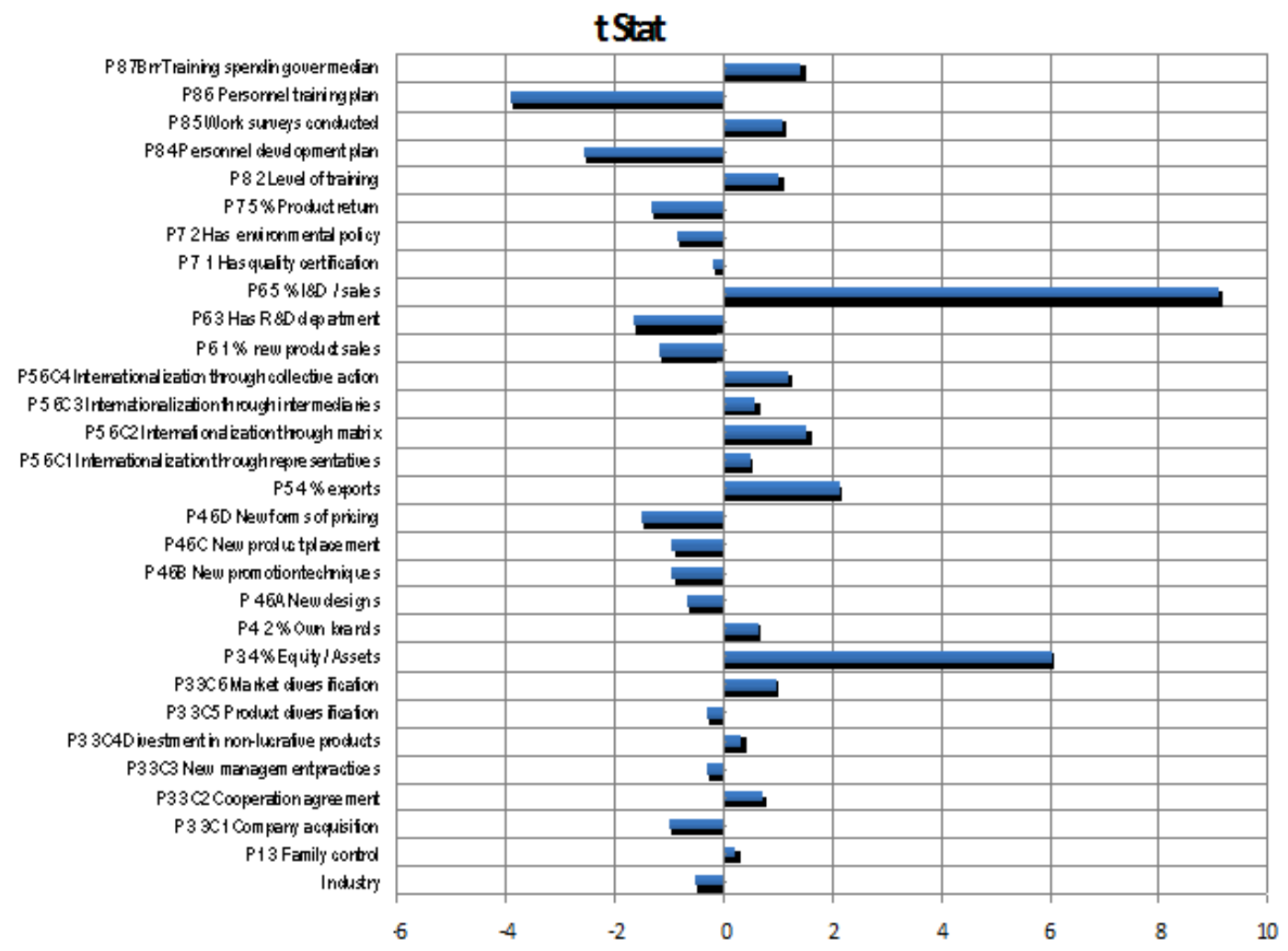

Figure 1. Summary of Student's t-test values for each variable 
Figure 1 shows the business strategy and practice variables that most influence growth, which are the percent of R\&D expenditures to sales, percent of exports invoiced; and percent of funding through a business' own resources.

\begin{tabular}{|c|c|c|c|c|c|c|c|c|c|}
\hline \multirow[b]{2}{*}{ Values } & \multicolumn{2}{|c|}{ Sales_increase } & \multirow[b]{2}{*}{$\begin{array}{l}\text { yes, a } \\
\text { lot }\end{array}$} & \multicolumn{3}{|c|}{ Profits_increase } & \multicolumn{3}{|c|}{ Employees_increase } \\
\hline & no & yes & & no & yes & $\begin{array}{l}\text { yes, a } \\
\text { lot }\end{array}$ & no & yes & $\begin{array}{l}\text { yes, a } \\
\text { lot }\end{array}$ \\
\hline P1_3_Family_control (\% of yes) & $50.0 \%$ & $40.0 \%$ & $72.7 \%$ & $49.4 \%$ & $46.2 \%$ & $66.7 \%$ & $50.0 \%$ & $40.7 \%$ & $85.7 \%$ \\
\hline $\begin{array}{l}\text { P3_3C1_Acquisition_of other companies (\% } \\
\text { of yes) }\end{array}$ & $17.5 \%$ & $8.0 \%$ & $18.2 \%$ & $17.3 \%$ & $7.7 \%$ & $22.2 \%$ & $17.1 \%$ & $7.4 \%$ & $28.6 \%$ \\
\hline $\begin{array}{l}\text { P3_3C2_Cooperation agreements with } \\
\text { other companies ( } \% \text { of yes) }\end{array}$ & $52.5 \%$ & $48.0 \%$ & $90.9 \%$ & $53.1 \%$ & $46.2 \%$ & $\begin{array}{r}100.0 \\
\%\end{array}$ & $53.7 \%$ & $51.9 \%$ & $85.7 \%$ \\
\hline $\begin{array}{l}\text { P3_3C4_Divestments_in_non_lucrative_pro } \\
\text { ducts ( } \% \text { of yes) }\end{array}$ & $21.3 \%$ & $12.0 \%$ & $27.3 \%$ & $22.2 \%$ & $7.7 \%$ & $33.3 \%$ & $22.0 \%$ & $14.8 \%$ & $14.3 \%$ \\
\hline P3_3C5_Product_diversification (\% of yes) & $62.5 \%$ & $60.0 \%$ & $72.7 \%$ & $63.0 \%$ & $57.7 \%$ & $77.8 \%$ & $63.4 \%$ & $55.6 \%$ & $85.7 \%$ \\
\hline P3_3C6_Market_diversification (\% of yes) & $57.5 \%$ & $76.0 \%$ & $63.6 \%$ & $58.0 \%$ & $69.2 \%$ & $77.8 \%$ & $58.5 \%$ & $74.1 \%$ & $57.1 \%$ \\
\hline $\begin{array}{l}\text { P3.4_Percentage_external_resources_/_(o } \\
\text { wn+external) }\end{array}$ & $35.8 \%$ & $66.9 \%$ & $74.1 \%$ & $35.1 \%$ & $70.9 \%$ & $73.9 \%$ & $36.0 \%$ & $71.0 \%$ & $68.6 \%$ \\
\hline P4_2_\%_own_brands & $2.0 \%$ & $1.9 \%$ & $2.3 \%$ & $1.9 \%$ & $2.1 \%$ & $2.9 \%$ & $2.0 \%$ & $2.3 \%$ & $0.6 \%$ \\
\hline P4_6A_New_designs (\% of yes) & $51.3 \%$ & $36.0 \%$ & $27.3 \%$ & $50.6 \%$ & $34.6 \%$ & $33.3 \%$ & $50.0 \%$ & $37.0 \%$ & $28.6 \%$ \\
\hline $\begin{array}{l}\text { P4_6B_New_promotion_techniques (\% of } \\
\text { yes) }\end{array}$ & $45.0 \%$ & $24.0 \%$ & $27.3 \%$ & $45.7 \%$ & $23.1 \%$ & $22.2 \%$ & $45.1 \%$ & $22.2 \%$ & $28.6 \%$ \\
\hline P4_6C_New_product_placement (\% of yes) & $43.8 \%$ & $20.0 \%$ & $27.3 \%$ & $42.0 \%$ & $26.9 \%$ & $22.2 \%$ & $43.9 \%$ & $18.5 \%$ & $28.6 \%$ \\
\hline P4_6D_New_forms_of_pricing (\% of yes) & $58.8 \%$ & $24.0 \%$ & $54.5 \%$ & $59.3 \%$ & $23.1 \%$ & $55.6 \%$ & $58.5 \%$ & $25.9 \%$ & $57.1 \%$ \\
\hline P5_4_\%_Exports over sales & $8.1 \%$ & $22.9 \%$ & $18.0 \%$ & $7.8 \%$ & $20.8 \%$ & $26.4 \%$ & $8.3 \%$ & $23.8 \%$ & $12.6 \%$ \\
\hline $\begin{array}{l}\text { P5_6C1_Internationalization_through_repre } \\
\text { sentatives ( } \% \text { of yes) }\end{array}$ & $15.0 \%$ & $20.0 \%$ & $36.4 \%$ & $13.6 \%$ & $23.1 \%$ & $44.4 \%$ & $14.6 \%$ & $25.9 \%$ & $28.6 \%$ \\
\hline $\begin{array}{l}\text { P5_6C2_Internationalization_through_matri } \\
\mathrm{x}(\% \text { of yes) }\end{array}$ & $2.5 \%$ & $16.0 \%$ & $9.1 \%$ & $2.5 \%$ & $15.4 \%$ & $11.1 \%$ & $2.4 \%$ & $18.5 \%$ & $0.0 \%$ \\
\hline $\begin{array}{l}\text { P5_6C3_Internationalization_through_inter } \\
\text { mediaries ( } \% \text { of yes }\end{array}$ & & $12.0 \%$ & $0.0 \%$ & $4.9 \%$ & $11.5 \%$ & $0.0 \%$ & $4.9 \%$ & $11.1 \%$ & $0.0 \%$ \\
\hline $\begin{array}{l}\text { P5_6C4_Internationalization_through_colle } \\
\text { ctive_action } \\
\text { (\% of yes) }\end{array}$ & $3.8 \%$ & $16.0 \%$ & $9.1 \%$ & $4.9 \%$ & $7.7 \%$ & $22.2 \%$ & $4.9 \%$ & $11.1 \%$ & $14.3 \%$ \\
\hline P6_1_\%_new_product_sales_over_sales & $18.5 \%$ & $27.1 \%$ & $13.8 \%$ & $19.3 \%$ & $21.9 \%$ & $20.0 \%$ & $19.4 \%$ & $25.7 \%$ & $4.6 \%$ \\
\hline P6_3_Has_R\&D_department (\% of yes) & $17.5 \%$ & $24.0 \%$ & $27.3 \%$ & $17.3 \%$ & $19.2 \%$ & $44.4 \%$ & $18.3 \%$ & $25.9 \%$ & $14.3 \%$ \\
\hline P6_5_\%_i\&d_」_sales & $0.3 \%$ & $2.2 \%$ & $3.6 \%$ & $0.4 \%$ & $2.0 \%$ & $3.7 \%$ & $0.5 \%$ & $2.3 \%$ & $3.3 \%$ \\
\hline P7_1_Has_quality_certification (\% of yes) & $36.3 \%$ & $64.0 \%$ & $45.5 \%$ & $37.0 \%$ & $57.7 \%$ & $55.6 \%$ & $37.8 \%$ & $59.3 \%$ & $42.9 \%$ \\
\hline P7_2_Has_environmental_policy (\% of yes) & $48.8 \%$ & $36.0 \%$ & $45.5 \%$ & $48.1 \%$ & $38.5 \%$ & $44.4 \%$ & $47.6 \%$ & $40.7 \%$ & $42.9 \%$ \\
\hline P7_5_\%_Product_return & $1.4 \%$ & $0.7 \%$ & $1.2 \%$ & $1.4 \%$ & $0.9 \%$ & $1.2 \%$ & $1.4 \%$ & $1.0 \%$ & $0.7 \%$ \\
\hline P8_2_calculs_Level_of_training (anys) & 12.97 & 13.08 & 13.05 & 12.95 & 13.01 & 13.47 & 12.96 & 13.10 & 13.09 \\
\hline $\begin{array}{l}\text { P8_4_Personnel_development_plan (\% of } \\
\text { yes) }\end{array}$ & $50.0 \%$ & $12.0 \%$ & $18.2 \%$ & $48.1 \%$ & $15.4 \%$ & $22.2 \%$ & $48.8 \%$ & $11.1 \%$ & $28.6 \%$ \\
\hline P8_5_Work_surveys_conducted (\% of yes) & $37.5 \%$ & $12.0 \%$ & $27.3 \%$ & $37.0 \%$ & $15.4 \%$ & $22.2 \%$ & $36.6 \%$ & $11.1 \%$ & $42.9 \%$ \\
\hline P8_6_Personnel_training_plan (\% of yes) & $60.0 \%$ & $16.0 \%$ & $18.2 \%$ & $60.5 \%$ & $15.4 \%$ & $11.1 \%$ & $58.5 \%$ & $14.8 \%$ & $28.6 \%$ \\
\hline $\begin{array}{l}\text { P8_7Brr_Training_spending_over_median } \\
\text { (\% of cases over median) }\end{array}$ & $38.8 \%$ & $52.0 \%$ & $36.4 \%$ & $40.7 \%$ & $38.5 \%$ & $55.6 \%$ & $40.2 \%$ & $48.1 \%$ & $28.6 \%$ \\
\hline
\end{tabular}

Table 2. Response percentage for each question as a function of growth

Table 2 includes a descriptive table for the "Yes, a lot," "Yes" or "No" answers in sales, profit and worker growth for each variable. This table details how each result is produced for 
variables that influence growth, and it corroborates the critical values in Student's t-distribution table.

These data are interpreted as follows. The questions are answered with "Yes" or "No". For example, in the question whether a company has a quality certification, $36.3 \%$ without increased sales had a quality certification. In contrast, $64 \%$ with increased sales had a quality certification, and $45.5 \%$ with greatly increased sales had such a certification.

Other questions ask for a percentage. In this case, the average percentage of the businesses in each group is generated, which is demonstrated in the following.

- In the question on whether a business' own resources were used for financing, companies without increased sales had less capital $(35.8 \%)$ than companies with somewhat increased sales $(66.9 \%)$ and greatly increased sales $(74.1 \%$ financed by their own resources)

- In the question on the export percentage for sales, companies that did not have increased sales had a smaller percentage of exports for their sales ( $8.1 \%)$ compared with companies that had somewhat or greatly increased sales.

- In the question on the percent of R\&D expenditures to sales, the businesses without increased sales had a $0.3 \%$ average $R \& D$ expenditure of the sales. In contrast, this value was $2.2 \%$ for companies with somewhat increased sales and $3.6 \%$ for companies with greatly increased sales. These data demonstrate that businesses with a sustained sales growth were characterized by focusing on quality, R\&D, exports and self-financing.

Finally, to further analyze the data, the values generated and shown in the graph as well as tables were compared through contingency tables and calculating the Pearson's chi-squared value for each variable. In each case (for each variable) the results were consistent with the values displayed.

\section{Conclusions, limitations and future research}

High-growth businesses are especially interesting because they significantly contribute to employment and countries' economic expansion. Prior studies have shown that the majority of high-growth businesses cannot sustain expansion over many years. Thus, this study sought to analyze the evolution of high-growth businesses and identify the determining factors that contribute to long-term growth or contraction.

The results show that the businesses with sustained sales, profits and employee growth over many years use the strategies that originally facilitated their growth. Thus, the primary contributing factors to a company's continued growth are capital (less debt) as the primary 
financing source; research and development investments; overall quality; and internationalization. These findings may be useful public managers that direct business development policy priorities as well as executives interested in creating and developing highsales and high-profit growth businesses.

This study has certain limitations. On one hand, it is focused on businesses with greater than 10 employees in Catalonia's industrial sector. Therefore, the conclusions generated may differ from those in other geographic locations or economic sectors as well as for smaller businesses. Moreover, this study was performed during an economic recession, which undoubtedly influenced economic evolution for the businesses analyzed.

Another aspect that should be clarified is that high-growth businesses are important, but they are not the only important businesses in a country's economic development. A desirable economy includes dynamic businesses, but typically such businesses are limited in dimension because (among other factors) smaller invoicing facilitates high growth rates. Clearly, countries are interested in large companies that compete on the global market.

Future research will include a broader scope for the geography and sectors studied. On the other hand, it is also important to repeat such studies under more favorable economic conditions.

\section{Note}

This work is part of a research project on high-growth businesses, which began in 1997 as part of the Industrial Prospects Observatory of the Department of Business and Employment of the Regional Government of Catalonia directed by Joan Miquel Hernández and Jordi Fontrodona. Certain primary publications from this research are included in the bibliography.

\section{References}

ACS, Z.; PARSONS, W.; TRACY, S. (2008). High-Impact Firms: Gazelles Revisited. Research Summary. U.S. Small Business Administration. 328.

ALCHIAN, A.A. (1950). Uncertainty, evolution and economic theory. Journal of Political Economy, 58: 211-222. http://dx.doi.org/10.1086/256940

AMAT, O.; FONTRODONA, J.; HERNÁNDEZ, J.M.; STOYANOVA, A. (2010). Les empreses d'alt creixement $i$ les gaseles a Catalunya (High-growth firms and gazelles in Catalonia). Barcelona: Generalitat de Catalunya.

BECHETTI, L.; TROVATO, G. (2002). The determinants of growth for small and medium sized firms. Small Business Economics, 19: 291-306. http://dx.doi.org/10.1023/A:1019678429111

BIRCH, D.; MEDOFF, J. (1994). Gazelles. In Solomon, L.C.; Levenson, A.R. (Eds.), Labor Markets, Employment Policy and Job Creation. Boulder: Westview Press. 159-167. 
CABANELAS, J.; VAAMONDE, A. (1995). Las empresas gacela de Galicia (Galician Gazelle Businesses). Análisis 1995. Vigo: Consorcio de la Zona Franca de Vigo.

CABANELAS, J.; VAAMONDE, A. (1996). Empresas gacela de Euskadi (Basque Gazelle Businesses). Bilbao: Sociedad para la Promoción y Reconversión Industrial.

CABRAL, L.; MATA, J. (2003). On the evolution of firm size distribution: facts and theory. The American Economic Review, 93: 1075-1095. http://dx.doi.org/10.1257/000282803769206205

COAD, A. (2009). The Growth of Firms. A Survey of Theories and Empirical Evidence, Chentelham: Edward Elgar Publishing Ltd.

DOWNIE, J. (1958): The Competitive Process, Londres: Duckworth.

ESADE (1996). La competitivitat de l'empresa industrial a Catalunya (The Competitiveness of Industrial Businesses in Catalonia). Barcelona: Edicions 62.

EUROSTAT (2007). Eurostat-OECD Manual on Business Demography Statistics. Paris: OECD Publications.

EVANS, D.E. (1987). The relationship between firm growth, size and age: Estimates from 100 manufacturing industries. Journal of Industrial Economics, 35(4): 567-581. http://dx.doi.org/10.2307/2098588

FISHER, E.; REUBER, A. (2003). Support for rapid growth firms: a comparison of the views of founders, government policymakers and private sector resource providers. Journal of Small Business Management, 41: 346-365. http://dx.doi.org/10.1111/1540-627X.00087

FREEL, M.S. (2000). Do small innovating firms outperform non-innovators? Small Business Economics, 14(3): 195-210. http://dx.doi.org/10.1023/A:1008100206266

GALVE, C.; HERNÁNDEZ, A. (2007). Empresas gacela y empresas tortuga en Aragón (Gazelle and Turtle Businesses in Aragon). Fundación Economía Aragonesa. Documento de Trabajo, 37.

GOEDHUYS, M.; SLEUWAEGEN, L. (2010). High-growth entrepreneurial firms in Africa: a quantile regression approach. Small Business Economics, 34: 31-51. http://dx.doi.org/10.1007/s11187-009-9193-7

HANNAN, M. y FREEMAN, J. (1977). The population ecology of organizations. American Journal of Sociology, 82(5): 929-964. http://dx.doi.org/10.1086/226424

HENKERSON, M.; JOHANSSON, D. (2008). Gazelles as job creators - a survey and interpretation of the evidence. IFN working paper series, 733. Stockholm: Research Institute of Industrial Economics.

HERNÁNDEZ, J.M.; AMAT, O.; FONTRODONA J.; FONTANA, I. (1999). Les empreses gasela a Catalunya (Gazelle Businesses of Catalonia). Papers d'Economia Industrial, 12. Departament d'Indústria, Comerç i Turisme. Barcelona: Generalitat de Catalunya. 
HOFFMANN, A.; JUNGE, M. (2006). Comparing the Number of High-growth Entrepreneurs across 17 Countries. FORA Working Paper, OCDE.

LOTTI, F.; SANTARELLI, E.; VIVARELLI, M. (2003). Does Gibrat's law hold among young small firms? Journal of Evolutionary Economics, 13: 213-235. http://dx.doi.org/10.1007/s00191-0030153-0

MARRIS, R. (1963). A model of managerial enterprise. Quarterly Journal of Economics, 77(2): 185-209. http://dx.doi.org/10.2307/1884399

MORALEDA, A. (2004). La innovación, clave para la competitividad empresarial (Innovation, key to business competitiveness). Universia Business Review, 1: 128-136.

MORENO, A. M.; CASILLAS, J.C. (2007). High-growth SMEs versus non-highgrowth SMEs: a discriminant analysis. Entrepreneurship \& Regional Development, 19(1): 69-88. http://dx.doi.org/10.1080/08985620601002162

NELSON, R.R. y WINTER, S.G. (1982). An Evolutionary Theory of Economic Change, Boston: Belknap Press of Harvard University Press.

PENROSE, E. (1959). The Theory of the Growth of the Firm. Londres: Blackwell Scientific Publications.

SERAROLS, C.; URBANO, D. (2007). El empresario y los factores de éxito [The Businessperson and the Factors in Success]. Revista de Contabilidad y Dirección, 5: 142-172.

VILLABA, F.; MUÑOZ, J.A.; ROMÁN, M.L.; MORILLA, F.; PÉREZ, S.; DÍAZ, R.M.; ÁLVAREZ, M. (2008). Referencias empresariales de Andalucía, empresas líderes, gacelas, de alto rendimiento y de alta productividad (Business Referencias of Analusia, Leading Businesses, Gazelles, High Performance and High Productivty). Málaga: Instituto de Análisis Económico y Empresarial de Andalucía.

YASUDA, T. (2005). Firm growth size, age and behavior in Japanese manufacturing. Small Business Economics, 24(1): 1-15. http://dx.doi.org/10.1007/s11187-005-7568-y

(C) Intangible Capital, 2013 (www.intangiblecapital.org)

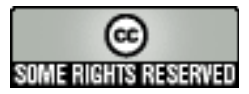

El artículo está con Reconocimiento-NoComercial 3.0 de Creative Commons. Puede copiarlo, distribuirlo y comunicarlo públicamente siempre que cite a su autor y a Intangible Capital. No lo utilice para fines comerciales. La licencia completa se puede consultar en http://creativecommons.org/licenses/by-nc/3.0/es/ 